\title{
Lead Concentration in Primary School Soil-Dust in Nigeria, Africa
}

\author{
P. A. Ekwumemgbo ${ }^{1}$ and K. I. Omoniyi ${ }^{2}$ \\ ${ }^{1}$ Department of Chemistry, Ahmadu Bello University, Zaria, Kaduna State, NIGERIA, pat_adamma@yahoo.com \\ ${ }^{2}$ Department of Chemistry, Ahmadu Bello University, Zaria, Kaduna State, NIGERIA, israelflourish@yahoo.com
}

\begin{abstract}
Lead in soil has been recognized as a public health problem, particularly among children. In recent years, attention has been directed to cumulative adverse effects of lead at low levels of intake. Leadcontaminated soil and dust have been identified as important contributors to blood lead levels. This work examines the total concentration of lead in primary school soil-dust in Nigeria. Soil-dusts were collected randomly from six geopolitical areas of Nigeria, digested and analysed for total lead concentration by Atomic Absorption Spectrophotometry. The mean lead concentration in the dry season for the North East (NE), North West (NW), North Central (NC), South South (SS), South East (SE), South West (SW) were 131.60 \pm 70.98 $\mathrm{mg} / \mathrm{kg}, 108.04 \pm 47.33 \mathrm{mg} / \mathrm{kg}, 72.94 \pm 55.45 \mathrm{mg} / \mathrm{kg}, 66.14 \pm 43.9 \mathrm{mg} / \mathrm{kg}, 45.98 \pm 34.60 \mathrm{mg} / \mathrm{kg}$ and $67.98 \pm$ $34.89 \mathrm{mg} / \mathrm{kg}$ respectively. In the raining season the mean lead concentration were $130.78 \pm 70.80 \mathrm{mg} / \mathrm{kg}$, $106.24 \pm 47.02 \mathrm{mg} / \mathrm{kg}, 70.96 \pm 55.52 \mathrm{mg} / \mathrm{kg}, 64.12 \pm 48.00 \mathrm{mg} / \mathrm{kg}, 44.58 \pm 28.90 \mathrm{mg} / \mathrm{kg}$, and $66.26 \pm 41.87$ $\mathrm{mg} / \mathrm{kg}$ respectively. This analysis is necessary to provide scientific data base for the loading of lead in classroom soil-dust in each zone. The authors recommend measurement and surveillance of lead blood level of the primary school children and a clean-up of both classrooms and the school environment.
\end{abstract}

Key words: Nigeria, soil-dust, lead, Atomic Absorption Spectrophotometry, concentration

\section{Introduction}

Heavy metals are elements having atomic weight between 63.545 and $200.50 \mathrm{~g}$ and a specific gravity (relative density) greater than $5.00 \mathrm{~g} / \mathrm{cm}^{3}$ (Jarup, 2003). The toxicity of these metals has been demonstrated throughout history: Greek and Roman physicians diagnosed symptoms of acute metal poisoning long before toxicology became a science. Heavy metals have been used for thousands of years, although several adverse health effects have been known, exposure continues, and are even increasing in some parts of the world, in particular, less developed countries (Jarup, 2003).

Lead is one of the heavy metals and has been used for at least 5000 years; early applications include building materials, pigments for glazing ceramics, and pipes for transporting water. It is a widespread contaminant in soils and widely distributed (Osoi, 2009). Lead contamination is generally higher in urban areas that display an older housing stock with lead-containing paint and heavy traffic (Shinn et al., 2000). Since it is highly immobile in soils, concern about soil contamination by lead persists despite the fact that most lead was removed from residential paints and gasoline approximately 25 years ago. It is distributed widely in the urban environment as a result of the weathering, scraping, sanding and sand blasting of structures bearing lead-based paint. Soil lead levels are generally highest at foundations of buildings that have been painted with exterior lead-containing paint. In addition, elevated lead levels persist in the soil near heavily traveled roads as a result of vehicle emissions from the combustion of gasoline containing tetraethyl lead. Unlike other metals, it has no biological role; ubiquitous in the environment; does not biodegrade or decay and potentially toxic to virtually every living thing including microorganisms (Sobolev and Begonia, 2008).

According to USDA (2000), acute poisoning from lead is feasible through ingestion or dermal contact. Exposure to lead is more dangerous for young and unborn children and elicited serious damage to human and the environment (Lenntech, 2009; Adelekan and Abegunde, 2011). Relationships and modes of transfer of lead from contaminated soil to children have been investigated. During play, lead can contaminate children's hands and may be transmitted to the mouth during oral behaviours (Lanphear et al., 2002).

The need to assess lead levels in classroom soil-dust in Nigeria was necessary due to the fact that the risk that 
toxic heavy metal pollution poses to humans was tragically demonstrated by the lead poisoning disaster that unfolded in Zamfara State, Nigeria in 2010. Investigations by the Joint United Nation Environment Programme/United Nation Office for the Coordination of Humanitarian (UNEP/OCHA) Environment Unit revealed that the cause of the health problems is acute lead poisoning from the processing of lead-rich ore used in the gold extraction process in homes and compounds in the affected areas. More than 18,000 people were affected and 200 children have reportedly died as a result of the poisoning. The United Nations urged Nigeria to prevent further lead poisoning in Nigeria and to implement measures to limit lead ore processing at sensitive sites, such as water sources which can easily become contaminated with the heavy metal (Blacksmith Institute's report, 2010).

\section{Materials and Methods}

Five primary schools were randomly selected from each of the six geopolitical zones in Nigeria namely North East (NE), North West (NW), North Central (NC), South South (SS), South East (SE) and South West (SW). Six soil-dust samples were randomly collected from six classrooms of each of the schools selected for the studies. These six samples from each primary school were pooled to form a single composite sample by the method of coning and quartering and stored in plastic vials.

The samples were prepared for laboratory analysis by Wet Digestion method in accordance to Standard Methods (Allen, 1974; APHA, 1998). Absorbance measurements were made at $217 \mathrm{~nm}$ using a single element hollow cathode lamp on a Basic Pye Unicam model 192 Atomic absorption spectrophotometer (AAS), equipped with automatic background correction. This was used to compensate for non-specific absorption and scattering of light, standard addition method was used to check matrix interference. The result of each sample was the average of ten sequential readings. The recovery rate of the concentration according to the certified values of the standard reference materials was $>95 \%$.

\section{Results and Discussion}

The results are expressed as the average of ten sequential determinations \pm the standard deviation and presented in Table 1. The data collected was analysed using SAS (statistical soft ware), and a 2-way ANOVA applied using the Duncan's Post-hoc multiple range test (DMRT) at $\mathrm{P}<0.05$ to assess differences in the mean values of the lead accumulated in the soil-dust samples due to geographical locations and seasonal changes. Pearson's correlation was used in reporting the statistical relationships that exist in the amount of lead burden in the soil-dust samples at the North and Southern cardinals of Nigeria $(\mathrm{P}<0.05)$.

As presented in Table 1, the mean lead concentrations in the dry season for the North East (NE),
North West (NW), North Central (NC), South South (SS), South East (SE), South West (SW) are $131.60 \pm$ $70.98 \mathrm{mg} / \mathrm{kg}, 108.04 \pm 47.33 \mathrm{mg} / \mathrm{kg}, 72.94 \pm 55.45$ $\mathrm{mg} / \mathrm{kg}, 66.14 \pm 43.9 \mathrm{mg} / \mathrm{kg}, 45.98 \pm 34.60 \mathrm{mg} / \mathrm{kg}$ and $67.98 \pm 34.89 \mathrm{mg} / \mathrm{kg}$ respectively. In the raining season the mean lead concentration were $130.78 \pm 70.80 \mathrm{mg} / \mathrm{kg}$, $106.24 \pm 47.02 \mathrm{mg} / \mathrm{kg}, 70.96 \pm 55.52 \mathrm{mg} / \mathrm{kg}, 64.12 \pm$ $48.00 \mathrm{mg} / \mathrm{kg}, 44.58 \pm 28.90 \mathrm{mg} / \mathrm{kg}$, and $66.26 \pm 41.87$ $\mathrm{mg} / \mathrm{kg}$ respectively.

The ranking for the loading of lead in the samples of the six geo-political zones is $\mathrm{SE}<\mathrm{SS}<\mathrm{SW}<\mathrm{NC}<\mathrm{NW}<$ NE. The soil-dust samples collected at the dry season showed remarkable increase in levels of lead loading compared to the raining season samples for all the geopolitical zones (Fig. 1). This could be accounted for by the fact that dry season is occasioned by wind that carries particulates containing several metal ions and the fact that dry season would facilitate the peeling of the surface of paint coatings that could release lead into classroom environment.

Duncan's multiple range test (DMRT) showed a high statistical difference in the amount of lead accumulated in the soil samples collected from the three Northern zones compared to the Southern zone $(\mathrm{P}<0.05)$ during the dry season. However, a less significant difference was indicated by the raining season samples. Pearson's correlation showed a high positive relationship in the mean amount of lead in the samples collected from the six geo-political zones during the dry season compared to the raining season counterpart $(r=0.829)$ with no statistical level of significance. Also Pearson's correlation showed a high positive relationship in the mean amount of lead in the dry and raining season: NE $(+0.939), \mathrm{NW}(+0.920), \mathrm{NC}(+0.913), \mathrm{SS}(+0.879), \mathrm{SE}$ $(+0.789)$ and SW $(+0.879)$.

The concentration of lead in the samples analysed were above the estimated natural lead concentration range of $5.00 \mathrm{mg} / \mathrm{kg}$ to $25.00 \mathrm{mg} / \mathrm{kg}$. The study found that the mean lead concentration from the NC, SS, SE and SW were below the maximum tolerable (permissible) limit according to World Health Organization (WHO) permissible limit of $100 \mathrm{mg} / \mathrm{kg}$ (Osoi, 2009). According to Shantha et al. (2005) who recommended maximum permissible levels of lead in soil based on the doseresponse relationship of lead in soil and blood lead in children stated that an acceptable level of $600 \mathrm{mg} / \mathrm{kg}$ of lead in soil is a "safe" level and would contribute no more than $5 \mu \mathrm{g} / \mathrm{dl}$ to total blood lead of children under 12 years of age. It is pertinent to state that recent data indicates that there may be neurotoxic effects of lead at lower levels of exposure than previously anticipated (Vasudevan and Streekumari, 2000).Children are the most vulnerable segments of the population for exposure to lead. This increased vulnerability results from combination of several factors for instance young children are more likely to play in dirt and place their hands and other objects in their mouth, thereby increasing the opportunity for soil ingestion (Pica-the eating of dirt and other non-food items is more likely to occur in 
children); the efficiency of lead absorption from the gastrointestinal tract and the permeable blood-brain barrier is greater in children than adults and nutritional deficiencies of iron, calcium, iron, copper and zinc which are prevalent in children, may facilitate lead absorption and exacerbate the toxic effect.

A legacy of incidents explains the seriousness of high levels of exposure to some metals (Bala et al., 2008). Generally it has been proved that lead disrupts the main structural components of the blood-brain barrier by primary injury to astrocytes with a secondary damage to the endothelial microvasculature within the brain, leadinduced damage occurs preferentially in the prefrontal cerebral cortex, hippocampus and cerebellum. Some characteristic clinical features of lead poisoning may be attributed to this specific anatomical pattern. Although the molecular targets for lead are unknown, a vast amount of evidence accumulated over many years has shown that lead disrupts processes that are regulated by calcium. Picomolar concentrations of lead can replace micromolar concentrations of calcium in a protein kinase $\mathrm{C}$ enzyme assay. Furthermore, lead activates protein kinase $\mathrm{C}$ in intact cells and induces the expression of new genes by a mechanism dependent on protein kinase $\mathrm{C}$ which leads to neurotoxicity (Bressler et al., 1999). The cellular, intracellular and molecular mechanisms of lead neurotoxicity are numerous, as lead impacts many biological activities at different levels of control: at the voltage-gated channels and on the first, second and third messenger systems. These effects could be related to lead's ability to interfere with the regulatory action of calcium in cell functions (Finkelstein et al., 1989). At a neuronal level, exposure to lead alters the release of neurotransmitter from presynaptic nerve endings. Spontaneous release is enhanced and evoked release is inhibited. The former may be due to activation of protein kinases in the nerve endings and the latter to blockade of voltage-dependent calcium channels. This disruption of neuronal activity may, in turn, alter the developmental processes of synapse formation and result in a less efficient brain with cognitive deficits (Bressler et al., 1999).

\section{Conclusion}

In developing countries, the extent of environmental pollution and ways to reduce and prevent exposures are only beginning to be understood. These nations have many competing health challenges and lead poisoning may be considered less important when there is uncertainty about population prevalence rates and the various correlates and sources of lead poisoning. Regulations designed to limit lead pollution are less common and less likely to be enforced compared with developed countries. The wide range in lead concentration in the classroom soil-dust from the five schools of each of the geo-political zone, call for caution in the schools to avert the means responsible for the elevation.

\begin{tabular}{|c|c|c|c|c|c|c|c|}
\hline \multicolumn{8}{|c|}{$\begin{array}{l}\text { Table } 1 \text { : Lead ce } \\
\text { Nigeria }(\mathrm{mg} / \mathrm{kg})\end{array}$} \\
\hline \multirow{2}{*}{ Zones } & \multicolumn{3}{|c|}{ Dry season } & \multicolumn{3}{|c|}{ Raining season } & \multirow[b]{2}{*}{$\mathrm{CC}$} \\
\hline & Min. & Max. & Mean \pm SD & Min. & Max. & Mean \pm SD & \\
\hline $\mathrm{NE}$ & 33.30 & 233.90 & $131.60 \pm 70.98$ & 32.80 & 232.90 & $130.78 \pm 70.80$ & +0.939 \\
\hline NW & 23.50 & 132.30 & $108.06 \pm 47.33$ & 22.30 & 131.40 & $106.24 \pm 47.02$ & +0.920 \\
\hline $\mathrm{NC}$ & 30.60 & 135.80 & $72.94 \pm 55.45$ & 28.80 & 133.80 & $70.96 \pm 55.52$ & +0.913 \\
\hline SS & 12.70 & 131.80 & $66.14 \pm 43.90$ & 10.60 & 128.50 & $64.12 \pm 48.00$ & +0.879 \\
\hline $\mathrm{SE}$ & 15.80 & 124.90 & $45.98 \pm 34.60$ & 15.00 & 124.20 & $44.58 \pm 28.90$ & +0.789 \\
\hline SW & 18.90 & 128.80 & $67.98 \pm 34.89$ & 17.80 & 126.20 & $66.26 \pm 41.87$ & +0.879 \\
\hline
\end{tabular}




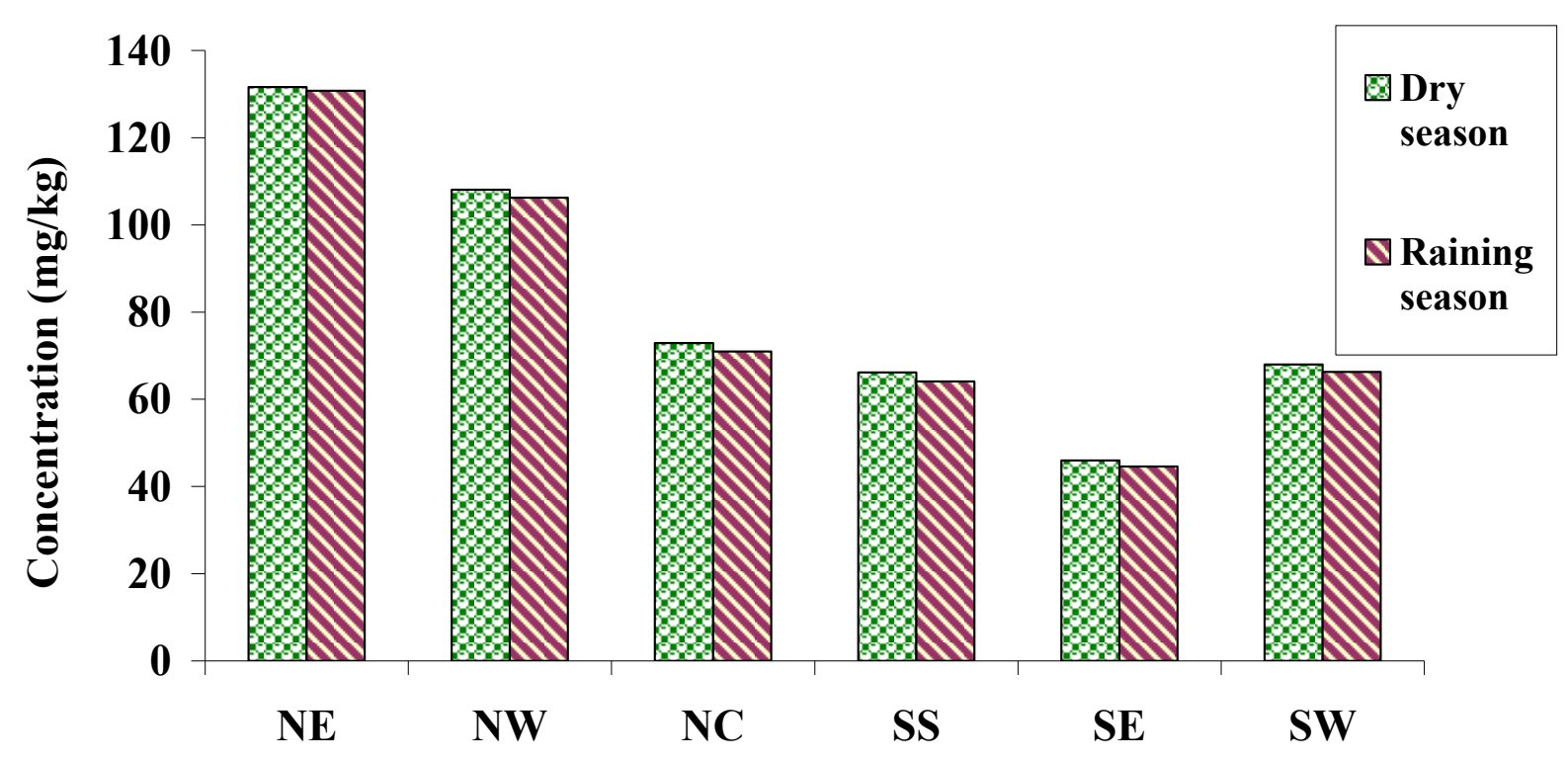

Geo-political zones

Fig. 1. Concentration of lead inclassroom soil-dust at the zones

\section{References}

Adelekan BA, Abegunde KD. Heavy metals contamination of soil and groundwater at automobile mechanic villages in Ibadan, Nigeria International Journal of the Physical Sciences 2011; 6(5): 1045-1058.

Allen SE. Grimshow H, Parkinson JA, Quarmby C. Chemical Analysis of Ecological Materials, (Oxford, London, 1974), p.565.

Osio V. Lead pollution due to vehicular emissions in urban areas in the Philippines. Soil and Environment. Soil and its relation to environment, agriculture, global warming, and human health (2009).

Bala M1, Shehu RA, Lawal M. Determination of the level of some heavy metals in water collected from two pollution - prone irrigation areas around Kano metropolis. Bayero Journal of Pure and Applied Sciences, (2008); 1(1): 36 - 38.

Blacksmith Institute's report. World's Worst Pollution Problems Report Top Six Toxic Threats. Produced in collaboration with Green Cross Switzerland (2010); p.76.

Ekwumemgbo PA. Bioaccumulation of Nickel in Soil and Plant Samples along a rail route. African Journal of Natural Science (2005); (8): 69-74.

Ekwumemgbo PA. Audu PA. Chromium and Zinc concentrations in agricultural soils. Biological and Environmental Science Journal for Tropics (2006); 3(4): 1 - 3 .

Järup L. Hazards of heavy metal contamination. Br. Medical Bulletin (2003); 68 (1): 167-182.
Lanphear BP, Hornung R, Ho M, Howard CR, Eberle S, Knauf K.Environmental lead exposure during early childhood. J Pediatr 2002;140:40 -47.

Lenntech WT. Chemical Properties, Health and Environmental Effects of Copper Lenntech Water Treatment and Purification (2009) www.lenntech.com /periodic/elements/cu.htm.

Shantha M, Kenneth DR, Terry S. Lead in soil: Recommended maximum permissible levels Environmental Research (2005); 49(1): 136- 142.

Shinn NJ, Bing-Canar J, Cailas M, Peneff N, Binns HJ. Determination of spatial continuity of oil lead levels in an urban residential neighbourhood.

Environmental Resources (2000); 81: 1-7.

Sobolev D, Begonia MFT. Effects of Heavy Metal Contamination upon Soil Microbes: Lead-induced Changes in General and Denitrifying Microbial Communities as Evidenced by Molecular Markers. Int. J. Environ. Res. Public Health, (2008); 5(5): 451.

United States Department of Agriculture, (USDA). Heavy Metals Contamination, Soil Quality Urban Technical Note 3, Natural Resources Conservation Service. (2000).

Vasudevan DM, Streekumari S. Biochemical aspect of environmental pollution Textbook of Biochemistry for Medical Students. $2^{\text {nd }}$ ed. Jaypee Brothers Medical Publishers, Ltd, New Delhi, India (2000); p. $485-467$. 